\title{
Does external debt lead to economic growth in Pacific island countries
}

\author{
T.K. Jayaraman ${ }^{\mathrm{a}, *}$, Evan Lau ${ }^{\mathrm{b}}$ \\ a School of Economics, Faculty of Business and Economics, The University of the South Pacific, Suva, Fiji \\ ${ }^{\mathrm{b}}$ Department of Economics, Faculty of Economics and Business, Universiti Malaysia Sarawak, \\ 94300 Kota Samarahan, Sarawak, Malaysia
}

Received 1 December 2007; received in revised form 1 March 2008; accepted 1 May 2008

Available online 6 June 2008

\begin{abstract}
With the change in donors' priorities since the end of the Cold War in the late 1980s, there has been a decline in annual aid inflows to Pacific island countries (PICs), which have been among the world's top recipients of aid per capita in the past. Along with fall in aid inflows, growing annual domestic budgetary deficits in recent years have forced some PICs to finance them through borrowing. This paper seeks to examine whether external debt contributed to economic growth in PICs by undertaking a study of six major PICs.

(C) 2008 Society for Policy Modeling. Published by Elsevier Inc. All rights reserved.
\end{abstract}

JEL classification: $\mathrm{F} 34 ; \mathrm{C} 23 ; \mathrm{O} 56$

Keywords: External debt; Exports; Budget deficits; Growth; Panel cointegration; Pacific islands

\section{Introduction}

Since their independence in the second half of last century, Pacific island countries (PICs) ${ }^{1}$ have been receiving substantial bilateral grant assistance each year from the two metropolitan powers in the region, namely Australia and New Zealand and the European Union as well as

\footnotetext{
* Corresponding author.

E-mail address: Jayaraman_tk@usp.ac.fj (T.K. Jayaraman).

1 There are 14 independent Pacific island countries, which constitute the official, international organization called Pacific Islands Forum. These are Cook Islands, Fiji, Kiribati, Marshall Islands, Federated States of Micronesia, Nauru, Niue, Palau, Papua New Guinea, Samoa, Solomon Islands, Tonga, Tuvalu and Vanuatu.
} 
other developed countries, including the United States, Japan and European Union. Such annual transfers, known as official development assistance (ODA) were helpful in bridging annual fiscal deficits and resource gaps between domestic savings and investment. They also served as cushion against pressures caused by annual current account deficits in their balance of payments and the resultant pressures on PICs' exchange rates. ${ }^{2}$ However, following changes in the priorities of the donor community in the late 1980s, annual ODA inflows have declined over the period. These developments along with growing annual domestic budgetary deficits forced some PICs to borrow. As there were limits to domestic borrowing, some PICs in recent times began to borrow from overseas in an increasing manner, aside from the traditional, international funding agencies. Fiji, for example, floated in 2006 an international bond in overseas capital markets, primarily to diversify its sources of borrowing.

This paper seeks to examine whether past external borrowing has contributed to economic growth in PICs. Due to data constraints, our study is confined to six major PICs, including Papua New Guinea (PNG) along with three other Melanesian countries (Fiji, Solomon Islands and Vanuatu) and two Polynesian countries (Samoa and Tonga). These are the only PICs having reliable national accounts data series for any meaningful analysis. However, the income data for four PICs, namely Samoa, Solomon Islands, Tonga and Vanuatu are available only from the mid 1980s. Since PICs share many commonalities, it is considered appropriate to resort to a panel data analysis. The paper is organised as follows. The next section reviews trends in external debt and growth; the third section outlines the modeling methodology while the fourth section presents empirical results. The final section draws some conclusions with policy implications.

\section{Trends in external debt and growth in PICs}

In the midst of substantial diversity in regard to land and other natural resources and population, the six PICs selected for the study share many commonalities. They relate to various constraints to growth: dependence on a narrow range of commodities for exports; strong reliance on tourism as major foreign exchange earner and provider of jobs; communal land tenure system, restricting the marketability of land as an economic commodity thereby inhibiting land based activities; isolation from major markets; proneness to natural disasters of all kinds; and external economic shocks. While foreign aid, as a proportion of GDP in all the six PICs decreased over a 12-year period, external debt as a proportion of GDP registered substantial increases in all PICs over the corresponding period, with the exception of Fiji (Table 1). The decline in Fiji's external debt, in particular, beginning from the late 1980s is attributed to a deliberate decision by the interim government after two military coups in 1987 , as a reaction to the forced isolation of the country by the international community. The elected governments in the 1990s continued the policy of reducing external debt level by prematurely retiring its outstanding debt.

Table 2 provides details of external debt incurred by the selected PICs. As of 2004, the latest year for which data are available (World Bank, 2006a), total external debt stock reflecting outstanding loans against the country, referred to as EDT and expressed as the percentage of country's GDP stands highest (150\%) in Samoa. The next in order are Solomon Islands (69\%), Papua New Guinea

\footnotetext{
${ }^{2}$ Six of the 14 PICs, namely Fiji, Papua New Guinea, Samoa, Solomon Islands, Tonga and Vanuatu have their own national currencies, while the remaining eight have been using currencies of their former rulers as legal tender.
} 
Table 1

Selected key indicators of six PICs

\begin{tabular}{|c|c|c|c|c|c|c|c|}
\hline & \multirow{2}{*}{$\begin{array}{l}\text { Population } \\
2005 \\
(' 000)\end{array}$} & \multirow{2}{*}{$\begin{array}{l}\text { Real GDP per } \\
\text { capita } 2005 \\
\text { (current price } \\
\text { in US\$) }\end{array}$} & \multirow{2}{*}{$\begin{array}{l}\text { Dev. index } \\
\text { ranking -2004 }\end{array}$} & \multirow{2}{*}{$\begin{array}{l}\text { Vulnerability } \\
\text { index } \\
\text { ranking-1997 }\end{array}$} & \multirow{2}{*}{$\begin{array}{l}\text { Aid per } \\
\text { capita } 2005 \\
\text { (in US\$) }\end{array}$} & \multicolumn{2}{|l|}{ Aid } \\
\hline & & & & & & $\begin{array}{l}1990(\% \text { of } \\
\text { GDP) }\end{array}$ & $\begin{array}{l}2005(\% \text { of } \\
\text { GDP) }\end{array}$ \\
\hline \multicolumn{8}{|l|}{ The Pacific } \\
\hline Fiji & 840 & 2195 & 90 & 9 & 61 & 3.9 & 1.8 \\
\hline PNG & 5600 & 714 & 139 & 31 & 40 & 12.8 & 7.2 \\
\hline Samoa & 181 & 1672 & 75 & 20 & 186 & 42.6 & 14.5 \\
\hline $\begin{array}{c}\text { Solomon } \\
\text { Island }\end{array}$ & 471 & 550 & 129 & 11 & 132 & 21.7 & 11 \\
\hline Tonga & 101 & 1629 & 55 & 3 & 270 & 26.3 & 16.4 \\
\hline Vanuatu & 215 & 1493 & 119 & 1 & 154 & 33 & 11.7 \\
\hline
\end{tabular}

Source: ADB (2006), World Bank (2006a).

(61\%), Tonga and Vanuatu (38\%) and Fiji (8\%). Among the six PICs, Fiji having been recently designated as a low middle-income country, is the only country, which is not presently eligible for borrowing on concessional terms ${ }^{3}$ from international agencies. As a consequence, concessional loans dominate EDT in all the other five PICs.

Concessional loans are about $98 \%$ of external debt in Tonga. The corresponding percentages for Solomon Islands, Vanuatu, Samoa, PNG and Fiji are respectively $82 \%, 77 \%, 46 \%, 36 \%$ and $16 \%$. If a large proportion of EDT is on concessional terms, annual total debt-servicing (TDS) costs, which include interest charges on outstanding debt and installments of principal, would remain small compared to total debt. Since debt servicing has to be effected in foreign exchange, the implications in terms of high opportunity costs of transfer of real resources are severe, especially in those years when foreign exchange earning capacity in terms of exports of goods and services (XGS) including tourism earnings, is adversely affected by natural disasters or man-made disasters such as political unrest. The best indicator of repayment capacity of the country is therefore the debt-servicing ratio (TDS/XGS).

In the case of the selected PICs, we find Samoa's debt-servicing ratio has been relatively high. On the other hand, Vanuatu's has been the least. Although PNG has been transferring sizeable foreign exchange (US\$ 474 million) towards debt servicing, the debt service ratio of PNG has been smaller than Samoa's since PNG's XGS are far more diversified in terms of minerals, oil and gas.

The annual GDP growth rates of PICs have been modest. While Samoa and Tonga fared better in the recent five-year period (2000-2004) than in the previous ten years, Fiji, PNG and Vanuatu did worse, although their growth rates were positive. On the other hand, the average growth rate of Solomon Islands was negative during 2000-2004. Thus, we have a picture of low growth rates in the selected PICs along with rise in external debt and budgetary deficits (Table 3).

\footnotetext{
${ }^{3}$ The terms and conditions of concessional loans from international agencies include low interest rate of $1 \%$, generally referred to as service charge and long periods of maturity ranging from 30 to 40 years together with a grace period, usually coinciding with the estimated period of project implementation.
} 
Table 2

Pacific island countries: external debt and debt service 1985-2004

\begin{tabular}{|c|c|c|c|c|c|c|c|c|}
\hline & 1985 & 1990 & 1995 & 2000 & 2001 & 2002 & 2003 & 2004 \\
\hline \multicolumn{9}{|l|}{ Fiji } \\
\hline External debt US\$ million & 443.7 & 403.1 & 246.1 & 134.2 & 114.3 & 140.1 & 203.1 & 201.8 \\
\hline EDT ( $\%$ of GDP) & 40.4 & 31.3 & 12.8 & 8.4 & 7.3 & 8.1 & 9.4 & 8.1 \\
\hline $\begin{array}{l}\text { Concessional debt ( } \% \text { of total external } \\
\text { debt) }\end{array}$ & 4.5 & 7.4 & 8.5 & 14 & 15.2 & 18.7 & 16.5 & 17.9 \\
\hline Total debt service paid (US\$ Million) & 63.6 & 105.6 & 66.3 & 29.7 & 22.9 & 21.7 & 18.3 & 14.6 \\
\hline $\begin{array}{l}\text { Debt service (TDS)/exports of goods } \\
\text { and services (XGS) }(\%)\end{array}$ & 11.7 & 12 & 5.8 & 2.9 & 2.0 & 1.6 & 1.2 & 0.9 \\
\hline \multicolumn{9}{|l|}{ Papua New Guinea } \\
\hline External debt US\$ million & 2112 & 2594 & 2306 & 2592 & 2505 & 2477 & 2464 & 2149 \\
\hline EDT (\% of GDP) & 90.5 & 83.7 & 56.5 & 78.8 & 89.3 & 94.6 & 83.6 & 61.4 \\
\hline $\begin{array}{l}\text { Concessional debt ( } \% \text { of total external } \\
\text { debt) }\end{array}$ & 15.7 & 21.6 & 32.1 & 35.4 & 32.1 & 34.9 & 36.2 & 41.8 \\
\hline Total debt service paid (US\$ million) & 340 & 553 & 626 & 306 & 270 & 277 & 294 & 474 \\
\hline $\begin{array}{l}\text { Debt service (TDS)/exports of goods } \\
\text { and services (XGS) }(\%)\end{array}$ & 32.5 & 37.2 & 20.8 & 12.9 & 12.7 & 15 & 11.9 & 17.1 \\
\hline \multicolumn{9}{|l|}{ Samoa } \\
\hline External debt US\$ million & 76.1 & 92 & 179.4 & 197.4 & 204.3 & 234.4 & 365.9 & 562 \\
\hline EDT (\% of GDP) & 81.6 & 56 & 88 & 85.5 & 85.7 & 90.3 & 115.1 & 150 \\
\hline $\begin{array}{l}\text { Concessional debt ( } \% \text { of total external } \\
\text { debt) }\end{array}$ & 67.9 & 90.5 & 94.6 & 73.4 & 69.2 & 66.1 & 45.9 & 31.2 \\
\hline Total debt service paid (US\$ million) & 7.7 & 5.5 & 4.6 & 8.5 & 7.4 & 7.8 & 13.1 & 21.1 \\
\hline $\begin{array}{l}\text { Debt service (TDS)/exports of goods } \\
\text { and services (XGS) }(\%)\end{array}$ & 15.1 & 5.8 & 4.3 & 10.7 & 9.1 & 9.3 & 13.6 & 19.0 \\
\hline \multicolumn{9}{|l|}{ Solomon Islands } \\
\hline External debt US\$ million & 65.5 & 120.5 & 158.7 & 155.4 & 163.2 & 179.8 & 178 & 176 \\
\hline EDT ( $\%$ of GDP) & 42.7 & 58.1 & 49.5 & 52 & 59.5 & 81.6 & 79.9 & 68.8 \\
\hline $\begin{array}{l}\text { Concessional debt ( } \% \text { of total external } \\
\text { debt) }\end{array}$ & 61.3 & 64.1 & 54.3 & 74.3 & 77.1 & 80.6 & 81.9 & 85.1 \\
\hline Total debt service paid (US\$ million) & 3.8 & 11.6 & 8.1 & 9.1 & 7.1 & 5.7 & 9.4 & 16.6 \\
\hline $\begin{array}{l}\text { Debt service (TDS)/exports of goods } \\
\text { and services (XGS) }(\%)\end{array}$ & 4.5 & 11.8 & 3.8 & 7.7 & 7.2 & 7.7 & 9.4 & 12.0 \\
\hline \multicolumn{9}{|l|}{ Tonga } \\
\hline External debt US\$ million & 24.4 & 51.9 & 62.8 & 60.2 & 58.2 & 67.6 & 79.5 & 81 \\
\hline EDT ( $\%$ of GDP) & 39 & 44.5 & 37.3 & 39.1 & 43.6 & 46.7 & 47.6 & 38.2 \\
\hline $\begin{array}{l}\text { Concessional debt ( } \% \text { of total external } \\
\text { debt) }\end{array}$ & 88 & 74.8 & 84 & 97.1 & 97.5 & 97.5 & 97.8 & 97.5 \\
\hline Total debt service paid (US\$ million) & 0.8 & 1.9 & 3 & 3.8 & 2.2 & 2.7 & 2.6 & 2.9 \\
\hline $\begin{array}{l}\text { Debt service (TDS)/exports of goods } \\
\text { and services (XGS) }(\%)\end{array}$ & 1.8 & 2.8 & 7.4 & 12.1 & 2.6 & 2.5 & 5.8 & 6.8 \\
\hline \multicolumn{9}{|l|}{ Vanuatu } \\
\hline External debt US\$ million & 15.8 & 38.2 & 48.9 & 74.5 & 71.6 & 90.5 & 94.8 & 118.3 \\
\hline EDT ( $\%$ of GDP) & 12.9 & 23.5 & 22.6 & 32.2 & 31 & 39.5 & 35.8 & 38.8 \\
\hline $\begin{array}{l}\text { Concessional debt ( } \% \text { of total external } \\
\text { debt) }\end{array}$ & 26.6 & 60.5 & 86.1 & 91.4 & 91.5 & 78.4 & 77.4 & 63.3 \\
\hline Total debt service paid (US\$ million) & 1.3 & 2.4 & 1.6 & 1.9 & 1.5 & 1.9 & 2.1 & 3.4 \\
\hline $\begin{array}{l}\text { Debt service (TDS)/exports of goods } \\
\text { and services (XGS) }(\%)\end{array}$ & 1.5 & 2.1 & 1.2 & 1 & 0.9 & 1.5 & 1.5 & 1.9 \\
\hline
\end{tabular}

Source: World Bank (2006b). 
Table 3

Pacific island countries: budget, trade and current account deficits (percentages of GDP)

\begin{tabular}{|c|c|c|c|c|c|c|c|c|c|c|c|c|c|c|c|}
\hline \multirow[t]{2}{*}{ PICs } & \multicolumn{3}{|c|}{$\begin{array}{l}\text { Budget deficit } \\
\text { averages }\end{array}$} & \multicolumn{3}{|c|}{$\begin{array}{l}\text { Trade deficits } \\
\text { averages }\end{array}$} & \multicolumn{3}{|c|}{$\begin{array}{l}\text { Current account } \\
\text { deficit averages }\end{array}$} & \multicolumn{3}{|c|}{$\begin{array}{l}\text { Broad money supply } \\
\text { averages }\end{array}$} & \multicolumn{3}{|c|}{ Growth rates (\%) } \\
\hline & 1990-1994 & 1995-1999 & 2000-2004 & 1990-1994 & 1995-1999 & 2000-2004 & +1990-1994 & $1995-1999$ & 2000-2004 & 1990-1994 & . $1995-1999$ & 2000-2004 & 1990-1994 & 1995-1999 & $2000-2004$ \\
\hline Fiji & 3.2 & 3.2 & 5.1 & 14.4 & 11.6 & 17 & 2.1 & 0.2 & 7 & 55.2 & 46.5 & 42.9 & 2.9 & 3 & 2 \\
\hline PNG & 3.7 & 0.8 & 1.5 & -14.7 & -21 & -26.5 & -3.8 & -4.6 & -4.3 & 33.5 & 33.3 & 23.9 & 8.9 & 2.4 & 2.1 \\
\hline Samoa & 10.5 & 0.2 & 1.3 & 68.3 & 38.7 & 41.4 & 13.2 & -5 & 0.2 & 40.2 & 33.3 & 38.8 & -1.5 & 3.9 & 4.3 \\
\hline $\begin{array}{r}\text { Solomon } \\
\text { Islands }\end{array}$ & 6.1 & 0.9 & 5.8 & 0.9 & -2.1 & 1.1 & 6.6 & -1.1 & -1.4 & 28.3 & 30 & 29 & 4.2 & 3.3 & -2.1 \\
\hline Tonga & 0 & 1.1 & 1.1 & 30 & -2.1 & 35.1 & -1.5 & 6.7 & 2.2 & 26.2 & 33.8 & 43.2 & 1.8 & 1.4 & 3.1 \\
\hline Vanuatu & 4.6 & 3.2 & 2.7 & 30.3 & 20.2 & 23.8 & 7.2 & 8.8 & 4.6 & 106.4 & 108.3 & 104.2 & 6.7 & 1 & 0.2 \\
\hline
\end{tabular}

Source: ADB (2006); Authors' calculations. 


\section{Modeling debt and growth nexus}

\subsection{Modeling and data}

If the governments find their annual budget deficits could not be financed by domestic borrowing they look to external sources for bridging the gaps. Additional attraction of external borrowing, which is always in hard currencies, such as the US dollar, the euro or yen, is that it adds to real resources of the country. Therefore, it becomes imperative that policy makers ensure prudent utilization of the loan proceeds by investing them in growth-oriented projects (Daesking \& Joshi, 2006; Adams, Sanchez, \& Adams, 1983; Kwack, 1983). Further, as growth enhances the image of the country in the eyes of the creditors in particular, higher growth would enable the country to borrow on better terms and hence would lead to further rise in debt level.

Since domestic markets of PICs are small in size, increased production of exportables following economic growth has to be sold overseas. Thus, growth is also positively associated with rise in exports of goods and services. A growing export sector as well as a thriving tourism service sector increases job opportunities and raises incomes, thus paving way for higher growth in GDP. Since debt servicing has to be effected in foreign exchange, better performance by these two foreign exchange earning sectors lowers the opportunity costs of transfer of resources involved in debt servicing (Daesking \& Joshi, 2006; Voyvoda \& Yedan, 2005; Kwack, 1983). Hence, it is postulated that higher export earning capability facilitates growth and budget deficits lead to rise in external borrowing. While domestic borrowing is entirely in domestic currency, external borrowing being in foreign exchange has an added advantage in terms of addition to real resources for the economy.

The study uses panel data covering a 17-year period (1988-2004) relating to six PICs for the empirical analysis. The data are drawn from the Global Development Finance, an annual publication of World Bank (2006a) and World Development Indicators, also an annual publication of World Bank (2006b). For our empirical study, we formulate the following functional relationship for panel data investigation.

$$
\mathrm{RGDP}=f(\mathrm{ED}, \mathrm{EXP}, \mathrm{BD}),
$$

where RGDP: real output in index numbers; ED: external debt as percentage of GDP; EXP: exports of goods and services as percentage of GDP; and BD: budget deficit as percentage of GDP.

\subsection{Panel unit root tests}

Recent advances in panel data analysis have focused attention on unit root and cointegration properties of variables observed over a relatively long span of time across a large number of cross-section units of countries. In this study, we adopt Maddala and Wu (1999), Hadri (2000), Levin, Lin, and Chu (2002) and Im, Pesaran, and Shin, 2003 panel unit root and stationarity tests. The null hypothesis of these tests is that the panel series has a unit root (non-stationary) except for the HADRI test. The HADRI test is similar to the KPSS type unit root test, with a null hypothesis of stationarity in the panel. For a detailed comparison of the procedures, see Appendix A. 


\subsection{Panel cointegration}

We thereafter proceed to examine whether there exists any long run equilibrium relationship between the variables under investigation. Towards this purpose, we resort to Pedroni's cointegration tests $(1999,2001,2004)$ that allow for heterogeneity in the intercepts and slopes of the cointegrating equation. Pedroni considers seven different statistics, four of which are based on pooling the residuals of the regression along the within-dimension (panel test) of panel and the other three are based on pooling the residuals of the regression along the between-dimension (group test) of the panel. The within-dimension tests take into account common time factors and allow for heterogeneity across countries. The between-dimension tests are the group mean cointegration tests, which allow for heterogeneity of parameters across countries. There are in all seven-panel cointegration test statistics, which are discussed in Appendix A.

\subsection{Panel fully modified OLS (FMOLS) estimates}

For obtaining appropriate estimates of the cointegrating relationship, we adopt the panel group mean Fully Modified OLS following the work by Pedroni (2000). The FMOLS procedure accommodates the heterogeneity that is typically present both in the transitional serial correlation dynamics and in the long run cointegrating relationships. The FMOLS estimator is described in Appendix A.

\subsection{Granger causality tests}

The procedures described above are only able to indicate whether or not the variables are cointegrated and a long run relationship exists between them. To test for panel causality, we estimate a panel-based vector error correction model (VECM) with a dynamic error correction term based on Holtz-Eakin, Newey, \& Rosen, 1988, 1989. The empirical models are represented by the following 4-equation of panel VECM.

$$
\begin{aligned}
& \Delta R G D P_{i t}=\pi_{1 j}+\sum_{p=1}^{m} \pi_{11 i p} \Delta R G D P_{i t-p}+\sum_{p=1}^{m} \pi_{12 i p} \Delta E D_{i t-p}+\leftrightarrow \sum_{p=1}^{m} \pi_{13 i p} \Delta E X P_{i t-p} \\
& +\sum_{p=1}^{m} \pi_{14 i p} \Delta B D_{i t-p}+\mu_{1 i} E C T_{i t-1}+\zeta_{1 i t} \\
& \Delta E D_{i t}=\pi_{2 j}+\sum_{p=1}^{m} \pi_{21 i p} \Delta E D_{i t-p}+\sum_{p=1}^{m} \pi_{22 i p} \Delta R G D P_{i t-p}+\leftrightarrow \sum_{p=1}^{m} \pi_{23 i p} \Delta E X P_{i t-p} \\
& +\sum_{p=1}^{m} \pi_{24 i p} \Delta B D_{i t-p}+\mu_{2 i} E C T_{i t-1}+\zeta_{2 i t} \\
& \Delta E X P_{i t}=\pi_{3 j}+\sum_{p=1}^{m} \pi_{31 i p} \Delta E X P_{i t-p}+\sum_{p=1}^{m} \pi_{32 i p} \Delta E D_{i t-p}+\leftrightarrow \sum_{p=1}^{m} \pi_{33 i p} \Delta R G D P_{i t-p} \\
& +\sum_{p=1}^{m} \pi_{34 i p} \Delta B D_{i t-p}+\mu_{3 i} E C T_{i t-1}+\zeta_{3 i t}
\end{aligned}
$$


$\Delta B D_{i t}=\pi_{4 j}+\sum_{p=1}^{m} \pi_{41 i p} \Delta B D_{i t-p}+\sum_{p=1}^{m} \pi_{42 i p} \Delta E D_{i t-p}+\leftrightarrow \sum_{p=1}^{m} \pi_{43 i p} \Delta E X P_{i t-p}$

$+\sum_{p=1}^{m} \pi_{44 i p} \Delta R G D P_{i t-p}+\mu_{4 i} E C T_{i t-1}+\zeta_{4 i t}$

where $\Delta$ is the lag operator, $p$ denotes the lag length. Here all variables are as previously defined. Using the specification in Equation 2 allows one to test causality direction. For example, in short run ED does not Granger cause RGDP where, $H_{0}: \pi_{12 i p}=0$ for all $i$ and $p$ while $\mu_{1 i}=0$ in Equation (2a) ${ }^{4}$. The rejection implies that ED causes RGDP. Similar analogous restrictions and testing procedure can be applied in testing the hypothesis that RGDP does not Granger cause movement in ED where the null hypothesis $\mathrm{H}_{0}: \pi_{22 i p}=0$ for all $i$ and $p$ while $\mu_{2 i}=0$ in Equation (2b).

\section{Empirical results}

\subsection{Panel unit root test results}

The results, which are summarized in Table 4, show that the series of the variables, RGDP, $\mathrm{ED}, \mathrm{EXP}, \mathrm{BD}$ are of an $I(1)$ process, as the pooled data are stationary in their first differences.

\subsection{Cointegration test}

Having established that all the four variables are integrated of the first order, we proceed to test whether there is a long run relationship of the system in panel data. From the panel cointegration results in Table 5, we find strong evidence to reject the null hypothesis of no cointegration for six out of the seven statistics provided by Pedroni (1999). Table 5 reveals rejection of the null of no cointegration for all cases except the panel PP type $\rho$-statistic. According to Pedroni (2004), the panel PP type $\rho$-test tends to under-reject the null in the case of small sample. Therefore, we conclude that our variables are in fact cointegrated. Rejection of the null hypothesis of no cointegration between the $I(1)$ series in the panel implies that the four variables do not drift apart in the long run steady state relationship. More importantly, the results indicate the benefits of using pooled panel data from which more variability can be exploited from the cross-sectional information. Despite the disparities in the individual countries, we found RGDP, ED, EXP and $\mathrm{BD}$ are cointegrated in the multi-country panel setting.

\subsection{Fully modified OLS estimates}

The long run estimates for each of the six PICs and for the panel of PICs, based on Pedroni's group mean FMOLS estimator, are reported in Table 6. The panel results of regression equation with RGDP as dependent variable show that the coefficients of ED and EXP are positive and statistically significant and the coefficient of BD is negative and significant. The magnitudes of

\footnotetext{
4 The F-test or Wald $\chi^{2}$ of the explanatory variables (in first differences) indicates the short run causal effects $\left(\pi_{12 i p}=\right.$ Ofor all $i$ and $p$ ) while the long run causal $\left(\mu_{1 i}=0\right)$ relationship is implied through the significance of the lagged ECT which contains the long run information.
} 
Table 4

Panel unit root tests results

\begin{tabular}{|c|c|c|c|c|c|c|}
\hline & \multicolumn{6}{|l|}{ Test statistics } \\
\hline & LLC & IPS & MW (ADF) & MW (PP) & HADRI & Conclusion \\
\hline \multicolumn{7}{|l|}{ A: Level } \\
\hline \multicolumn{7}{|c|}{ Model specification: individual effects } \\
\hline RGDP & $0.988(0.838)$ & $1.940(0.973)$ & $5.006(0.957)$ & $5.305(0.947)$ & $3.550(0.000)$ & - \\
\hline ED & $-1.254(0.105)$ & $-1.091(0.137)$ & $12.988(0.369)$ & $5.320(0.946)$ & $3.161(0.000)$ & - \\
\hline EXP & $-0.639(0.261)$ & $-0.180(0.428)$ & $17.943(0.117)$ & $17.686(0.125)$ & $5.058(0.000)$ & - \\
\hline BD & $-0.668(0.252)$ & $-0.342(0.365)$ & $8.233(0.766)$ & $16.748(0.159)$ & $3.447(0.000)$ & - \\
\hline \multicolumn{7}{|c|}{ Model specification: individual effects and individual linear trends } \\
\hline RGDP & $-0.344(0.365)$ & $-0.828(0.203)$ & $11.605(0.477)$ & $12.692(0.391)$ & $3.989(0.000)$ & - \\
\hline ED & $-0.492(0.311)$ & $1.187(0.882)$ & $5.541(0.937)$ & $13.963(0.303)$ & $2.176(0.014)$ & - \\
\hline EXP & $-0.230(0.408)$ & $0.676(0.750)$ & $12.527(0.404)$ & $16.420(0.172)$ & $5.162(0.000)$ & - \\
\hline $\mathrm{BD}$ & $0.339(0.632)$ & $-0.884(0.188)$ & $13.140(0.358)$ & $16.729(0.160)$ & $3.962(0.000)$ & - \\
\hline \multicolumn{7}{|c|}{ B: First differences } \\
\hline \multicolumn{7}{|c|}{ Model specification: individual effects } \\
\hline$\triangle \mathrm{RGDP}$ & $-4.572(0.000)$ & $-3.715(0.000)$ & $36.559(0.000)$ & $46.142(0.000)$ & $0.515(0.303)$ & $I(1)$ \\
\hline$\Delta \mathrm{ED}$ & $-3.835(0.000)$ & $-2.930(0.001)$ & $26.358(0.009)$ & $62.855(0.000)$ & $0.639(0.261)$ & $I(1)$ \\
\hline$\triangle \mathrm{EXP}$ & $-4.797(0.000)$ & $-7.206(0.000)$ & $39.394(0.000)$ & $70.685(0.000)$ & $-1.416(0.921)$ & $I(1)$ \\
\hline$\Delta \mathrm{BD}$ & $-5.792(0.000)$ & $-4.601(0.000)$ & $27.461(0.006)$ & $71.265(0.000)$ & $-0.817(0.793)$ & $I(1)$ \\
\hline \multicolumn{7}{|c|}{ Model specification: individual effects and individual linear trends } \\
\hline$\triangle \mathrm{RGDP}$ & $-5.178(0.000) \mathrm{s}$ & $-3.689(0.000)$ & $33.405(0.000)$ & $37.289(0.000)$ & $0.930(0.176)$ & $I(1)$ \\
\hline$\Delta \mathrm{ED}$ & $-3.546(0.000)$ & $-2.280(0.011)$ & $22.172(0.035)$ & $53.105(0.000)$ & $1.063(0.143)$ & $I(1)$ \\
\hline$\Delta \mathrm{EXP}$ & $-3.348(0.000)$ & $-5.129(0.000)$ & $26.278(0.009)$ & $60.906(0.000)$ & $0.005(0.497)$ & $I(1)$ \\
\hline$\Delta \mathrm{BD}$ & $-6.831(0.000)$ & $-4.433(0.000)$ & $24.061(0.020)$ & $52.435(0.000)$ & $1.032(0.151)$ & $I(1)$ \\
\hline
\end{tabular}

Notes: IPS, LLC and HADRI indicated the Im et al. (2003), Levin et al. (2002) and Hadri (2000) panel unit root and stationary tests. MW (Fisher-ADF) and MW (Fisher-PP) denotes Maddala and Wu (1999) Fisher-ADF and Fisher-PP panel unit root test. The IPS, LLC, MW (Fisher-ADF) and MW (Fisher-PP) examine the null hypothesis of non-stationary while HADRI tests the stationary null hypothesis. The four variables were grouped into one panel with sample $N=17, T=6$. The parenthesized values are the probability of rejection. Probabilities for the MW (Fisher-ADF) and MW (Fisher-PP) tests are computed using an asymptotic $\chi^{2}$ distribution, while the other tests follow the asymptotic normal distribution.

Table 5

Heterogeneous panel cointegration results

\section{Test Statistics}

Panel cointegration statistics (within-dimension)

Panel $\nu$-statistic

$3.498(0.001)$

Panel PP type $\rho$-statistic

Panel PP type $t$-statistic

$1.065(0.226)$

Panel ADF type $t$-statistic

$-2.358(0.002)$

$3.594(0.001)$

Group mean panel cointegration statistics (between-dimension)

Group PP type $\rho$-statistic

Group PP type $t$-statistic

$2.291(0.002)$

Group ADF type $t$ - statistic

$-4.425(0.000)$

$3.693(0.000)$

Notes: The number of lag truncations used in the calculation of the seven Pedroni statistics is 3. Probability values are in parenthesis. 
Table 6

Fully modified OLS estimates

\begin{tabular}{lllr}
\hline Countries & ED & EXP & BD \\
\hline Fiji & $1.650(10.640)^{*}$ & $1.460(2.400)^{*}$ & $0.620(2.920)^{*}$ \\
PNG & $0.080(3.340)^{*}$ & $3.580(5.180)^{*}$ & $-2.870(-2.980)^{*}$ \\
Samoa & $0.480(4.690)^{*}$ & $0.550(2.900)^{*}$ & $-0.910(-3.840)^{*}$ \\
Solomon Islands & $0.340(2.910)^{*}$ & $0.560(0.710)$ & $-1.460(-2.570)^{*}$ \\
Tonga & $1.450(2.480)^{*}$ & $0.570(2.580)^{*}$ & $-1.520(-7.920)^{*}$ \\
Vanuatu & $0.810(2.470)^{*}$ & $1.550(0.780)^{*}$ & $-4.600(-2.820)^{*}$ \\
Panel Group & $0.290(5.910)^{*}$ & $0.830(2.500)^{*}$ & $-1.460(-4.920)^{*}$ \\
\hline
\end{tabular}

Notes: The number of lag truncations used in the calculation of the seven Pedroni statistics is 3 . The values in parentheses are $t$-statistics. Asterisk (*) shows significance at $5 \%$ level.

the estimated coefficients of ED, EXP and BD, whose signs are in accordance with theoretical expectations, denote the long run elasticities of output with respect to external debt, exports and budget deficits. One percent rise in external debt stock contributes $0.25 \%$ rise in national output. The elasticity estimate of RGDP with respect to exports is 0.83 , indicating $1 \%$ increase in exports leads to $0.83 \%$ rise in output. The elasticity estimate of RGDP with respect to budget deficit is 1.46 , indicating $1 \%$ rise in budget deficit leads to decline in output by $1.46 \%$ confirming the crowding out effect of budget deficit on private sector.

The signs of the coefficients of ED in all estimated country equations with RGDP as dependent variable are consistent with a priori expectations and are also statistically significant. An increase in external debt would trigger correspondingly an upward rise in growth. The elasticity estimates range from 0.08 (PNG) to 1.65 (Fiji). The results suggest that external debt contributes most to Fiji's output, whereas it contributes least to PNG's output.

The results also indicate a positive and significant relationship between EXP and RGDP for all the countries except for Solomon Islands. In the case of Solomon Islands, the coefficient of EXP is not significant, although the sign is positive. The magnitudes of elasticity measures for RGDP with respect to exports for PNG, Vanuatu and Fiji are more than unity, whereas in the case of Samoa and Tonga, they are less than one.

As regards the elasticity measures of RGDP with respect to $\mathrm{BD}$, we find that only in the case of Fiji, budget deficit has positively and significantly contributed to growth. In respect of all other countries, budget deficit has retarded growth.

\subsection{Granger causality results}

Given the fact that all the series under investigation are cointegrated, Eq. (2) was estimated using the panel-based VECM with a dynamic error correction term based on Holtz-Eakin et al. $(1988,1989)$. The main interest of the exercise is to establish the causal linkages between external debt and growth. The empirical results presented in Table 7 are summarized, as follows. In the long run, we observe there is no Granger causality relationship between RGDP and ED, EXP and $\mathrm{BD}$, as the coefficient of the error correction term (ECT) in the equation with RGDP as dependent variable is not statistically significant. In the short run, there is a significant causal relationship running from ED, EXP and BD to RGDP, based on the Chi-square statistics of the coefficients of the three variables.

In regard to relationship between ED and the three variables, RGDP, EXP, and BD, we find a similar absence of long run causality running from the latter three to ED. However, we note in the 
Table 7

Panel granger causality results

\begin{tabular}{|c|c|c|c|c|c|c|}
\hline \multirow{2}{*}{$\begin{array}{l}\text { Dependent } \\
\text { variables }\end{array}$} & \multirow{2}{*}{$\begin{array}{l}\Delta \mathrm{RGDP} \\
\chi^{2} \text {-statistics } \\
(p \text {-value })\end{array}$} & \multirow[t]{2}{*}{$\Delta \mathrm{ED}$} & \multirow[t]{2}{*}{$\Delta \mathrm{EXP}$} & \multirow[t]{2}{*}{$\Delta \mathrm{BD}$} & \multicolumn{2}{|l|}{ ECT } \\
\hline & & & & & Coefficient & $t$-ratio \\
\hline$\Delta \mathrm{RGDP}$ & - & $21.651(0.000)$ & $11.699(0.019)$ & $15.340(0.004)$ & 0.029 & 0.650 \\
\hline$\Delta \mathrm{ED}$ & $8.170(0.085)$ & - & $6.475(0.166)$ & $0.682(0.954)$ & -0.032 & -0.423 \\
\hline
\end{tabular}

Notes: Parenthesized values are the probability of rejection of Granger non-causality. $\Delta$ is the first different operator. Estimations are based on the pooled data for 1988-2004 and 6 Pacific island countries $(N=6, T=17)$ with three lags.

short run the causality runs only from RGDP to ED, where there is no such short run causality linkage running from either EXP or $\mathrm{BD}$, to ED.

\section{Summary and policy implications}

In recent years, Pacific island countries have been relying more on external borrowing for financing their development programs and projects in the context of declining annual aid inflows and rising domestic budget deficits. With the exception of Fiji, the outstanding debt stock of five PICs is dominated by concessional loans.

The PICs are open economies highly dependent on all imports, ranging from food and fuel to capital goods and transport machinery. Against the background of limited range of exports of goods and services, comprising only primary and primary processed products, which include sugar in Fiji, copra and fish in Solomon Islands and Tonga, and minerals in the case of PNG, besides tourism, export promotion becomes an important target component of economic growth. Since external debt-servicing obligations have to be met in foreign exchange, utilization of external loan proceeds in either foreign exchange earning or import saving projects, becomes critically important. 5

Utilizing a panel data of six selected PICs on output (RGDP), external debt (ED), annual budget deficits (BD), exports of good and services (EXP), the paper investigated the relationship between external debt and growth in PICs during the 17-year period (1988-2004). Focusing on relationship between external debt and growth, the empirical study findings indicate that (i) although there is no long-term relationship, in the short run there is a causal linkage running from external debt, budget deficit and exports to output; and (ii) there is a short run bi-directional causal relationship between economic growth and external debt. The conclusions are: since external borrowing contributes to growth in PICs in the short run, growth enhances the image of a PIC as an efficient user of borrowed funds, enabling it to borrow from abroad on better terms; consequently, higher growth results in further rise in external debt level.

The findings have important policy implications. PICs are benefited by external borrowing in the short run, which have been dominated by concessional loans from World Bank and Asian Development Bank. Debt servicing of concessional loans over a long period of 30 years including

\footnotetext{
5 An IMF study on the debt-to-export dynamics relating in respect of 72 low-income countries has established conditions for a given debtor country would be more favourable (i) the higher the country's growth rate of exports relative to the concessional interest rate, with the effect being magnified when the initial debt ratio is large; (ii) the smaller is its financing gap; (iii) the higher the concessionality of its debt; and (iv) the more export-oriented it is, that is, the higher its share of exports in GDP (Daesking \& Joshi, 2006).
} 
grace period of no payment at all does not impose a heavy burden, especially when the country's export earning capacity is given a boost by such loans, as the present value of these future transfers duly discounted would be much smaller than the face value of the debt. As debt servicing involves a smaller, annual real resource transfer compared to that would have been involved in commercial loans, PICs are willing to borrow on regular intervals in the short run from the international agencies. Secondly, since growth in output would improve the credibility of PICs, the international lending agencies are encouraged to lend frequently and more willingly than before.

The implications of the study findings are of equal interest to developed countries who as bilateral donors, have been annually assisting PICs with grants since the 1950s. Despite the steady annual aid inflows, PICs were found to be performing poorly with average annual rate of growth being less than $2 \%$, in comparison to the similarly placed island nations in the Indian Ocean, and the Caribbean regions, such as Mauritius (6\%) and Barbados (4\%). The weak growth performance of PICs in the midst of plentiful aid was described as Pacific Paradox by a World Bank study on Pacific islands (1992), which called for new directions in aid strategies, including donor coordination and aid delivery, including gradual reduction in annual budget support and its eventual discontinuance, and tying grants to projects and programs.

However, as progress in better aid delivery and management was slow, a study provocatively titled as Aid has Failed the Pacific? (Hughes, 2003) under the auspices of the Australian thinktank, the Centre for Independent Studies severely criticized the effectiveness of foreign aid to the Pacific island countries. Hughes (2003) noted that most of the aid, which totaled US\$ 50 billion during 30 years (1951-2000) was spent on government consumption by elites and bureaucracy, and often diverted from the intended purposes, as aid was fungible. ${ }^{6}$ Two empirical studies on aid effectiveness in PICs (Jayaraman \& Choong, 2006; Jayaraman \& Ward, 2006) noted that each year, on an average, about $80 \%$ of government budget was spent on house keeping expenditures dominated by wages and salaries. The findings of these two studies were that aid funds should have been directed towards outer island development projects, concentrating on physical infrastructure such as ports and roads connecting farms as well as the hinterland in remote, isolated islands to market centres and main harbours for speedy movement of surplus agricultural production as exports, so that rural communities are benefited through rises in their incomes (Jayaraman \& Ward, 2006).

While bilateral donors' aid moneys were mostly spent on government consumption, loans from international agencies have always been for specifically earmarked projects and sector or programs. Any grants given by Asian Development Bank and World Bank, which are regularly piggy-backed to loans, have been for technical assistance towards training the local staff and institutional strengthening as well as for project implementation purposes.

Further, the borrowing governments have to commit themselves in terms of budget provisions in advance for implementation in terms of both local funds and foreign exchange and they have to submit their claims in the following year to lending agencies for reimbursement of the funds spent in the preceding year. The fungible nature of funds is thus eliminated to a large extent. Furthermore, implementation of loan projects and sector/ program loans is not only closely monitored with submission of regular reports but also guided and helped by periodical missions from

\footnotetext{
${ }^{6}$ Most of the bilateral aid programs are for "soft" projects, such as prevention of child abuse, empowerment of women, AIDS awareness and the like (Hughes, 2003), where seminars and discussions are held with lavish lunches and expensive cocktail receptions attended by the elites and bureaucracies.
} 
the headquarters or by offices located in the countries or regions. ${ }^{7}$ Further, there are always conditionalities, which involve requirements of policy and institutional reforms in steps so that the release of funds is effected in tranches.

In the case of aid programs by the bilateral governments, conditionalities are singularly absent, which explains to a great deal why aid often became fungible and how funds earmarked for a given purpose and mostly upfront, unlike in the case of loans from international financing agencies, got diverted for other purposes, mostly for consumption by governments. Independent evaluators of aid effectiveness have in the past recommended that donor countries should channel more of their aid program funds through international agencies, who could administer them on their behalf through appropriate mix of loans and grants to developing countries. Although the spirit of such recommendation was much appreciated by donors, the developed countries, because of their own independent geo-political interests, appeared to be reluctant to go along with the suggestion. ${ }^{8}$

It is now increasingly recognized that aside from tourism, PICs have to rely upon exports of agricultural products and processed agricultural products for their growth, as their domestic markets are small. The study finding confirms that there is a relationship between growth and external debt and exports in PICs. Thus, it is clear external borrowing for projects and programs towards strengthening the export earning capacity is well justified.

\section{Appendix A. Panel estimation: unit root, cointegration and fully modified OLS}

\section{A.1. Different procedures for unit root tests}

This note is based on surveys, which include Banerjee (1999), Baltagi and Kao (2000), Breitung and Pesaran (2008, Chap. 9). These tests are also available in the manual of Eviews (see http://www.eviews.com). Further, Hlouskova and Wagner (2006) also provide a survey on the performance of the panel unit root and stationarity tests.

Maddala and Wu (1999, MW) developed the test statistics that is based on combining the $p$-values of any given test statistic for a unit root in each cross-sectional unit ( $p_{i}$ say for the $i$ th cross-section, $i=1, \ldots, N)$. This is a version of non-parametric test that was based on Fisher (1932). The MW test statistics is given as

$$
P(\lambda)=-2 \sum_{i=1}^{N} \log \left(p_{i}\right),
$$

where $p_{\mathrm{i}}$ is the $p$-value of the test statistic for unit $i$ distributed as a $\chi^{2}$ with degree of freedom twice the number of cross-section units $(2 N)$ under null hypothesis. The Fisher test is an exact and non-parametric test and may be computed for any arbitrary choice of a test for the unit root in a cross-sectional unit. In this paper, we adopted both the ADF and the Phillips-Perron individual unit root tests in order to construct the MW test statistic.

\footnotetext{
${ }^{7}$ Recognizing the importance of loan supervision, the World Bank and Asian Development Bank have in recent years opened more sub regional offices and country offices to supervise loan implementation.

8 The result has been that most of the aid programs funded by donors result in duplication of efforts, leading to considerable wastage of scarce resources. Further, in the absence of effective coordination amongst aid giving countries, the recipient countries take advantage of the situation by playing one donor against another.
} 
In addition, the Levin et al. (2002) test was build upon their earlier paper of Levin and Lin (1993). This approach is easily describes in the following regression of

$$
\Delta x_{i t}=\gamma_{i} x_{i t-1}+e_{i t} \quad \text { for } \quad i=1, \ldots, N \text { and } t=1, \ldots, T .
$$

According to these authors, the panel estimator can be defined as

$$
\sqrt{N} T(\hat{\gamma}-1)=\frac{(1 / \sqrt{N}) \sum_{i=1}^{N}(1 / T) \sum_{t=1}^{T} x_{i t-1} e_{i t}}{(1 / N) \sum_{i=1}^{N}\left(1 / T^{2}\right) \sum_{t=1}^{T} x_{i t-1}^{2}} .
$$

The following $t$-statistics can be used to test for the null hypothesis of panel unit root of

$$
t_{\gamma}=\frac{(\widehat{\gamma}-1) \sqrt{\sum_{i=1}^{N} \sum_{t=1}^{T} x_{i t-1}}}{\sqrt{1 / N T} \sum_{i=1}^{N} \sum_{t=1}^{T} e_{1 t}^{2}} .
$$

The Im et al. (2003, IPS) had proposed $t$-bar statistic that is based on the average of the individual ADF $t$-statistics in order to examine the unit root hypothesis for panels. They evaluate the null hypothesis as $\mathrm{H}_{0}: \beta_{i}=0$ for all $i$, against the alternative that all the series are stationary, $\mathrm{H}_{1}: \beta_{i}<0$ for all $i$. In short, the test statistics of $t$-bar are given as

$$
\Gamma_{\bar{t}}=\frac{\sqrt{N}\left\{\bar{t}_{N T}-E\left(t_{T} \mid \beta_{i}=0\right)\right.}{\sqrt{\operatorname{Var}\left(t_{T} \mid \beta_{i}=0\right)}} \Rightarrow N(0,1), \quad \text { where } \quad \bar{t}_{N T}=(1 / N) \sum_{i=1}^{N} t_{i T},
$$

such that $\bar{t}_{N T}$ is the average ADF $t$-statistics for individual countries. The terms $E\left(t_{T} \mid \beta_{i}=0\right)$ and $\operatorname{Var}\left(t_{T} \mid \beta_{i}=0\right)$ are the finite common mean and variance of the individual ADF statistics $t_{i T}$, tabulated in IPS. The test statistics converges to the standard normal distribution as $T$ (time periods dimension) and $N$ (cross-sectional dimension of the panel) tends to infinity and $N / T$ tends to zero under the null hypothesis of unit roots, $\beta_{i}=0, i=1,2, \ldots, N$.

Unlike the other panel unit root test, Hadri (2000) test seeks to test the null hypothesis of stationarity in the panel. It is based on the residuals from the individual OLS regression of $y_{i t}$ on a constant, or on a constant and trend. We specified the general form specification that includes both constant and a trend as

$$
y_{i t}=\alpha_{i t}+\beta_{t} t+\varepsilon_{i t},
$$

where $\alpha_{i t}$ is a random walk: $\alpha_{i t}=\alpha_{i t-1}+\theta \cdot u_{i t}$ where both $u_{i t}$ and $\alpha_{i t}$ are generated from $N(0,1)$. The stationary null hypothesis is expressed as $\mathrm{H}_{0}: \sigma_{u}^{2}=0$. The test statistic for the null hypothesis of one-sided LM test for stationary null hypothesis is defined as

$$
\mathrm{LM}=\frac{\sum_{i=1}^{N} \sum_{t=1}^{T} S_{i t}^{2}}{N \cdot T^{2} \varpi^{2}}
$$

where $S_{i t}=\sum_{j=1}^{t} \varepsilon_{i j}$ and $\varpi^{2}$ is the consistent Newey and West (1987) estimates of the long run variance of distribution terms $\varepsilon_{i t}$ defined as $\sigma_{i}^{2}=\left\{\lim _{T \rightarrow \infty} E\left(S_{i T}^{2}\right)\right\} / T$. To avoid the size distortions, the truncation lag is set equal to the integer of $4(T / 100)^{1 / 4}$ in the Bartlett window.

\section{A.2. Panel cointegration test statistics}

There are in all seven-panel cointegration tests. Detailed description of the formulae for the seven-panel cointegration statistics, are given in Pedroni (1999: 660-661). 
(A) Within-dimension (panel tests):

(a) Panel $\nu$-statistic,

(b) Panel Phillips-Perron (PP) type $\rho$-statistics,

(c) Panel Phillips-Perron (PP) $t$-statistic (non-parametric),

(d) Panel augmented Dickey Fuller (ADF) $t$-statistic (parametric),

(B) Between-dimension (group tests):

(e) Group Phillips-Perron (PP) type $\rho$-statistics,

(f) Group Phillips-Perron (PP) $t$-statistic (non-parametric),

(g) Group augmented Dickey Fuller (ADF) $t$-statistic (parametric).

These seven statistics are based on the estimated panel cointegration regression residuals of the likely cointegrating vector,

$$
\mathrm{RGDP}_{i, t}=\alpha_{i}+\phi_{i} t+\beta_{1} \mathrm{ED}_{i, t}+\beta_{2} \mathrm{EXP}_{i, t}+\beta_{3} \mathrm{BD}_{i, t}+\varepsilon_{i, t},
$$

varying across countries, thus permitting full heterogeneity $\left(\beta_{i}\right)$, fixed effects $\left(\alpha_{i}\right)$ and individual specific deterministic trends $\left(\phi_{i} t\right)$ across individual members of the panel.

Pedroni (1999) shows that under appropriate standardization based on the moments of vector of Brownian motion function, each of these statistics converges weakly to a standard normal distribution when both the $T$ and $N$ of the panel grow large. The standardized distributions for the above mentioned seven panel and group statistics can be expressed in the form of

$$
\frac{e_{N, T}-\mu \sqrt{N}}{\sqrt{v}} \Rightarrow N(0,1)
$$

where $e_{N, T}$ is the respective panel/group cointegration statistic and $\mu$ and $v$ are the expected mean and variance of the corresponding statistics. They are computed by Monte Carlo stochastic simulations and tabulated in Pedroni (1999, Table 2).

\section{A.3. Fully modified OLS estimates}

Following Pedroni (2000, 2001), we consider the following cointegrated system for panel data of

$$
\begin{aligned}
& Y_{i t}=\alpha_{i}+\beta_{i} X_{i t}+\mu_{i t}, \\
& X_{i t}=X_{i, t-1}+e_{i t},
\end{aligned}
$$

where $i=1,2, \ldots, N$ countries over the time period of $i=1,2, \ldots, M$. In addition, $Z_{i t}=\left(Y_{i t}\right.$, $\left.X_{i t}\right)^{\prime} \sim I(1)$ and $\zeta_{i t}=\left(\mu_{i t}, e_{i t}\right)^{\prime} \sim I(0)$ with covariance matrix of $\Omega_{i}=\Omega_{i}^{0}+\Gamma_{i}+\Gamma_{i}^{\prime}$ where $\Omega_{0}^{i}$ is the contemporaneous covariance, $\Gamma_{i}$ is the weighted sum of autocovariances while $\Omega_{i}=L_{i} L_{i}^{\prime}$ in which $L_{\mathrm{i}}$ is the lower triangular decomposition of $\Omega_{i}$. For simplicity, we assume that $Y=$ RGDP while $X$ [ED, EXP, BD] of Eq. (1) and A.8 in this study. The panel FMOLS estimator for coefficient $\beta$ is given as

$$
\beta_{\mathrm{FM}}^{*}=N^{-1} \sum_{i=1}^{N}\left(\sum_{t=1}^{T}\left(X_{i t}-\bar{X}_{i t}\right)^{2}\right)^{-1}\left(\sum_{t=1}^{T}\left(X_{i t}-\bar{X}_{i t}\right) Y_{i t}^{*}-T \hat{\gamma}_{i}\right),
$$


where

$$
Y_{i t}^{*}=\left(Y_{i t}-\bar{Y}\right)-\frac{\hat{L}_{21 i}}{\hat{L}_{22 i}} \Delta X_{i t} \quad \text { and } \quad \hat{\gamma}_{i}=\hat{\Gamma}_{21 i}+\hat{\Omega}_{21 i}^{0}-\frac{\hat{L}_{21 i}}{\hat{L}_{22 i}}\left(\hat{\Gamma}_{22 i}+\hat{\Omega}_{22 i}^{0}\right) .
$$

Likewise, the associated $t$-statistics for the estimator can be constructed as

$$
t_{\hat{\beta}_{\mathrm{FM}}^{*}}=N^{-1 / 2} \sum_{i=1}^{N} t_{\hat{\beta}_{\mathrm{FM}, i}^{*}} \quad \text { where } \quad t_{\hat{\beta}_{F M, i}^{*}}=\left(\hat{\beta}_{F M, i}^{*}-\beta_{0}\right)\left(\hat{\Omega}_{11 i}^{-1} \sum_{t=1}^{T}\left(X_{i t}-X_{i}\right)^{2}\right)^{1 / 2} .
$$

\section{References}

Adams, F., Sanchez, E. P., \& Adams, M. E. (1983). Can Latin America carry its international debt? A prospective analysis using the Wharton Latin American debt simulation model. Journal of Policy Modeling, 5(3), 419-441.

Asian Development Bank (ADB) (2006). Key Indicators of Developing Asian and Pacific Countries 2006, Manila: ADB.

Baltagi, B., \& Kao, C. (2000). Nonstationary panels. Cointegration in panels and dynamic panels: a survey. In B. Baltagi, T. B. Fomby, \& R. C. Hill (Eds.), Advances in Econometrics: Nonstationary Panels, Cointegration in Panels and Dynamics Panels (pp. 7-51).

Banerjee, A. (1999). Panel data unit roots and cointegration: an overview. Oxford Bulletin of Economics and Statistics, 61, 607-629.

Breitung, J., \& Pesaran, M. H. (2008). Unit roots and cointegration in panels. In L. Matyas \& P. Sevestre (Eds.), The Econometrics of Panel Data: Fundamentals and Recent Developments in Theory and Practice (pp. 279-322). Kluwer Academic Publishers.

Daesking, C., \& Joshi, B. (2006). Debt and new financing in low-income countries: looking back, thinking ahead. In Peter Isard, Peter Isard, et al. (Eds.), The Macroeconomic Management of Foreign Aid: Opportunities and Pitfalls. Washington, D.C.: International Monetary Fund.

Fisher, R. A. (1932). Statistical Methods for Research Workers. Edinburgh: Oliver and Boyd.

Hadri, K. (2000). Testing for stationarity in heterogeneous panel data. Econometrics Journal, 3, 148-161.

Hlouskova, J., \& Wagner, M. (2006). The performance of panel unit root and stationarity tests: results from a large scale simulation study. Econometric Reviews, 21, 85-116.

Holtz-Eakin, D., Newey, W., \& Rosen, H. (1988). Estimating vector autoregressions with panel data. Econometrica, 56, 1371-1395.

Holtz-Eakin, D., Newey, W., \& Rosen, H. (1989). The revenues-expenditure nexus: evidence from local government data. International Economic Review, 30, 415-429.

Hughes, H. (2003). Aid has Failed the Pacific. Issue Analysis No. 33. Canberra: Centre for Independent Studies.

Im, K. S., Pesaran, M. H., \& Shin, Y. (2003). Testing for unit roots in heterogeneous panels. Journal of Econometrics, $115,53-74$.

Jayaraman, T. K., \& Ward, B. (2006). Aid effectiveness in a vulnerable island nation: an empirical study on aid-growth nexus in Vanuatu. Asia Pacific Development Journal, 13(2), 93-112.

Jayaraman, T. K., \& Choong, C. K. (2006). Aid and economic growth in Pacific island countries. Perspectives on Global Development and Technology, 5(4), 329-350.

Kwack, S. Y. (1983). Developments and prospects for external debt position and burden of developing countries. Journal of Policy Modeling, 5(3), 443-459.

Levin, A., Lin, C.F., 1993. Unit root tests in panel data: New results. Discussion Paper No. 56. University of California at San Diego (UCSD).

Levin, A., Lin, C. F., \& Chu, C. S. J. (2002). Unit root tests in panel data: asymptotic and finite sample properties. Journal of Econometrics, 108, 1-24.

Maddala, G. S., \& Wu, S. (1999). A comparative study of unit root tests with panel data and a new simple test. Oxford Bulletin of Economics and Statistics, 61, 631-652.

Newey, W., \& West, K. (1987). A simple positive semi-definite, heteroskedasticity and autocorrelation consistent covariance matrix. Econometrica, 55, 703-708.

Pedroni, P. (1999). Critical values for cointegration tests in heterogeneous panels with multiple regressors. Oxford Bulletin of Economics and Statistics, 61, 653-670.

Pedroni, P. (2000). Fully modified OLS for heterogeneous cointegrated panels. Advances in Econometrics, 15, 93-130. 
Pedroni, P. (2001). Purchasing power parity tests in cointegrated panels. The Review of Economics and Statistics, 83, 727-731

Pedroni, P. (2004). Panel cointegration: asymptotic and finite sample properties of pooled time series tests with an application to the PPP hypothesis. Econometric Theory, 20, 597-625.

Voyvoda, E., \& Yedan, E. (2005). Managing Turkish debt: an OLG investigation of the IMF's fiscal programming model for Turkey. Journal of Policy Modeling, 27, 743-765.

World Bank. (2006). Global Development Finance, Vol. 2, Country Tables. Washington, D.C.: World Bank.

World Bank (2006b). World Development Indicators [CD Rom 2007]. Washington, D.C.: World Bank. 